\title{
機器分析による土砂試料の異同識別に関する基礎研究
}

\author{
青木英士*1，保倉明子*1，中井 泉*1，寺田靖子*2 \\ 東京理科大学理学部応用化学科*1, 高輝度光科学研究センターSPring $-8 * 2$ \\ 干162-8601 東京都新宿区神楽坂 1-3*1 \\ 干679-5198 兵庫県佐用郡佐用町光都 1-1-1*2
}

\section{Fundamental Research for Forensic Characterization of Soil Samples by Using Instrumental Analysis}

\author{
Eishi Aoki*1, Akiko Hokura*1, Izumi Nakai*1 and Yasuko Terada*2 \\ Department of Applied Chemistry, Faculty of Science, Tokyo University of Science ${ }^{* 1}$ \\ 1-3 Kagurazaka, Shinjuku-ku, Tokyo 162-8601 Japan \\ SPring-8, Japan Synchrotron Radiation Research Institute*2 \\ 1-1-1 Kouto, Sayo-cho, Sayo-gun, Hyogo 679-5198 Japan
}

(Received 20 April 2007; accepted 1 June 2007)

Soil can be one of the most important physical evidence in a criminal investigation which contributes to prove a linkage between the suspect and the crime scene. In this work, the validity of multiple instrumental analytical techniques for forensic soil identification was studied using 148 soil samples collected from the Tokyo metropolitan area. The samples were characterized by X-ray diffraction (XRD) analysis, X-ray fluorescence (XRF) analysis, magnetic susceptibility determination, scanning electron microscopy with an energy dispersive X-ray spectrometer (SEMEDS) and high-energy synchrotron radiation X-ray fluorescence (SR-XRF) analysis. It was found that soil samples collected from railway stations and roadside dust showed higher magnetic susceptibilities $\left(\geqq 0.5 \times 10^{-4} \mathrm{~m}^{3} \mathrm{~kg}^{-1}\right.$ for $25 \%$ of the samples collected ) than those of soil samples collected from rivers, ponds, and lakes $\left(<0.1 \times 10^{-4} \mathrm{~m}^{3} \mathrm{~kg}^{-1}\right.$ for $40 \%$ of the samples colleted $)$. Microscopic examination of the soil samples revealed three kinds of characteristic spherules: i.e., transparent, white, and black particles. The SEM-EDS analyses of the spherule samples showed the following compositional characteristics. The transparent spherules exhibited two compositional types: $\mathrm{Na}-\mathrm{Ca}-\mathrm{Si}-\mathrm{O}$ and $\mathrm{Ba}-\mathrm{Ti}-\mathrm{Si}-\mathrm{O}$ types. On the other hand, black ones were either $\mathrm{Fe}-\mathrm{O}$ or $\mathrm{Si}-\mathrm{Mg}-\mathrm{O}$ types and white ones were either $\mathrm{Al}-\mathrm{O}$ or $\mathrm{Sr}-\mathrm{Al}-$ O types. It was concluded that these six types of spherules were found at characteristic points and consequently, they can be used as forensic soil identification.

Key words: Forensic characterization, Soil samples, Spherules, SR-XRF, Magnetic susceptibility 


\section{緒 言}

土砂は地表に広く分布し地域的特徵を持つことか ら，場所と人との関連を証明する証拠資料として科 学捜査において重要視されてきた ${ }^{1)}$. 実際にこれま で，誘拐や殺人が土砂の地質学的証拠に基づいて解 決するケースが多く存在している．たとえば，殺 人・死体遺棄事件で，被害者の衣服に付着していた 土砂と殺人現場の土砂，被疑者の靴や自動車に付着 していた土砂と殺人現場あるいは死体遺棄現場の土 砂の異同識別を行うことによりこれらの関連が証明 された2)。また，身代金受け取り後に警察から逃れ た誘拐犯が犯行に使用した車の後部座席に付着して いた足跡から特定されたケースもある3).

基礎研究としては，Marumoによる優れた総説4) があるほか, 国内では山梨県・韮崎の土砂試料に関 して Sugita and Marumoにより土砂の色，粒径分 布の研究が行われている5,6)。 また, Hiraokaは京 都地方で採取された土砂試料に関して, 蛍光X線分 析法に基づく組成分析結果を多变量解析することに より試料の特性化を行った ${ }^{7)}$. 海外では, Graves が 土砂試料を顕微鏡下で観察し鉱物の同定と迅速な計 数を行い，14のカテゴリーに分類した ${ }^{8)}$. Janssen らは土砂の同定に試料の粘土の色を観察する方法を

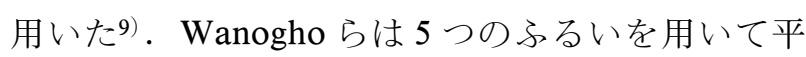
均粒径を計算することで 6 つのグループに分類し た ${ }^{10)}$.

近年，異同識別作業の一環として，いろいろな証 拠物件を対象とするデータベースの作成が，わが国 はもとより，世界の多くの国で盛んとなっている.

Hiraoka の研究7)では, 土砂試料のデータベース作 成を試みているが，東京のような人工物が混在して いる都心部においては行われていないのが現状であ る. また，多発する犯罪に土砂試料を役立てるため には，明確で迅速な分析法の確立が必要とされてい る.

そこで本研究では，データベース作成へ向けての 基礎検討として，首都圏で採取した土砂を試料と し，物質史情報11)を反映する指標物質の探索および 鉱物鑑定のような熟練の経験によらずに実行可能な 分析方法, 特に機器分析を用いた手法の開発を目的 とした。
試料は, 地質学的な観点だけでなく過去に犯罪が 発生した場所や発生が予測される地点 $10 \mathrm{~km} \times 10$ $\mathrm{km}$ の範囲から数箇所選択した。一般的に土砂の前 処理法としてはフッ酸や塩酸を用いて不要な鉱物な どを取り除くが，これでは重要な証拠になりうる試 料までもが, 溶解, 变質により失われてしまう恐れ がある，そこで，本研究ではイオン交換水とアル コールを用いて簡便的に前処理を行うこととした。 長石 [密度 : $2.47 \sim 2.76 \mathrm{~g} \mathrm{~cm}^{-3}$ ] と石英 [密度 : $\left.2.65 \mathrm{~g} \mathrm{~cm}^{-3}\right]$ の地殸中での存在率は合わせて約 80 \%である12)ことから，このような地款中に多量に含 まれる鉱物を取り除き，指標物質となりうる個別粒 子を探索するには, 重液を用いた分離が有効であ る. そこで本研究では, 人体に害がなく, また, 水 との混合比により比重を2.3～3.1に調整可能なポリ タングステン酸ナトリウム $\left[3 \mathrm{Na}_{2} \mathrm{WO}_{4} \cdot 9 \mathrm{WO}_{3} \cdot \mathrm{H}_{2}\right.$ $\mathrm{O}, \mathrm{SOMETU}$ 製] 溶液を用いた重液分離 ${ }^{13)}$ を行っ た.

今回, 採取地点の影響を反映するバルク試料の分 析と決定的な証拠となりうる個別粒子の分析の 2 通 りについて研究を進めた。 まず，バルク試料に関し て高密度物質の存在率の比較, 質量磁化率測定, 蛍 光 $\mathrm{X}$ 線分析 $(\mathrm{XRF})$, 粉末 $\mathrm{X}$ 線回折分析 (XRD) を 行った. バルク試料の分析では, 全体の特徴を見出 すために重液分離前の乾燥試料を用いた.

採取した試料には様々な鉱物, 人工物が含まれて いるために様々な密度を持つ物質が混在している. その試料中に高密度物質（密度 $\geqq 3.02 \mathrm{~g} \mathrm{~cm}^{-3}$ ) が どれだけ含まれているのか表記したものが高密度物 質の存在率である. 質量磁化率は, 磁化の強さと磁 場の強さの比で帯磁率ともいう.

個別粒子に関しては石英, 長石などを取り除いた 重液分離後の高密度フラクションを重点的に調べ た. 本論文では顕微鏡下で容易に発見できる球体に 着目し特性化を試みた. 天然の鉱物による特性化に ついては, 現在さらに解析を進めている. 組成分析 にはエネルギー分散型X線分析装置付き走査型電子 顕微鏡（SEM-EDS）を，結晶性物質の同定分析に は一粒で回折パターンが得られるガンドルフィーカ メラ14,15)を用いた。 また, 微量重元素による異同識 別を試みるために高エネルギー放射光蛍光 X 線分 
析（SR-XRF）を行った.

\section{実 験}

1. 試料

\section{1-1 サンプリング}

東京近郊の地表部の土砂を各箇所 1 点ずつ約 100 $\mathrm{g}$ 採取し, 採取地点を河川 - 池 · 湖 (24点), 公園 (69点), 寺 - 神社 (15点), 駅 · 道路 (40点) の 4 種類に区分した。 また，サンプリングを行った地点 の正確な位置をソニー（株）製の GPS [PCQHGR3S］で記録し，ソフトウェアには（株）ゼン リン製の Navin’ You 5.5を使用した。採取地点を Fig. 1 に示す.

\section{1-2 洗浄}

サンプリングした試料を以下の分析に使用するた め，洗浄を行った。 まず，たばこの吸壳や石など分 析に関係ない物質を取り除くために，あらかじめ 1 $\mathrm{mm}$ 以下に篩い分けした試料を $500 \mathrm{ml}$ ビーカーに 入れ，熱湯，イオン交換水，メタノールを用いて順 次洗浄を行い, 乾燥機中 $100^{\circ} \mathrm{C}$ で乾燥させた. 洗浄 の際, 超音波洗浄器を用いることでデカンテーショ ンを容易にし，試料の損失をできるだけ抑えた。乾 燥時間は試料によりばらつきがあったが，いずれも 完全に乾燥するまで 8～12時間を要した.

\section{1-3 重液分離}

洗浄済反の土砂試料に関して，比重（密度）の大
小で分別するため重液分離を行った．重液として用 いるポリタングステン酸ナトリウム溶液の比重は, 比重ガラスを用いて確認しながら2.96〜3.02に調整 した．重液分離後の試料は，それぞれイオン交換水 を用いて超音波洗浄した後に乾燥させた。重液分離 後の高密度フラクション, 低密度フラクション（密 度 $3.02 \mathrm{~g} \mathrm{~cm}^{-3}$ ) の質量を電子天秤で秤量し，高 密度物質の存在率（=高密度フラクションの質量/ (高密度フラクションの質量＋低密度フラクション の質量)）を各地点で算出して比較した．重液分離 前の乾燥試料, 重液分離後の高密度フラクション, 低密度フラクションをそれぞれ別のサンプル瓶に保 管し，以下の測定試料とした。

\section{2. 質量磁化率測定}

岩石では，磁鉄鉱などの磁性鉱物の含有率により 様々な磁化率を持ちうる. 土砂試料については様々 な鉱物，人工物の集合体であると考えられるので， 質量磁化率の違いは土砂試料の異同識別の指標とな りうる。そこで，洗浄済みの土砂試料について質量 磁化率を測定した。質量磁化率は以下の式により求 められる16).

$$
\chi_{g}=C \times\left(\frac{l}{m}\right) \times \delta
$$

$\chi_{g}$ : 質量磁化率 $\left(\mathrm{m}^{3} \mathrm{~kg}^{-1}\right), C$ : 磁気天秤の校 正定数, $\delta:$ 見かけの重量変化

$l:$ 試料管底面からの試料の高さ $(\mathrm{cm}), m:$ 試

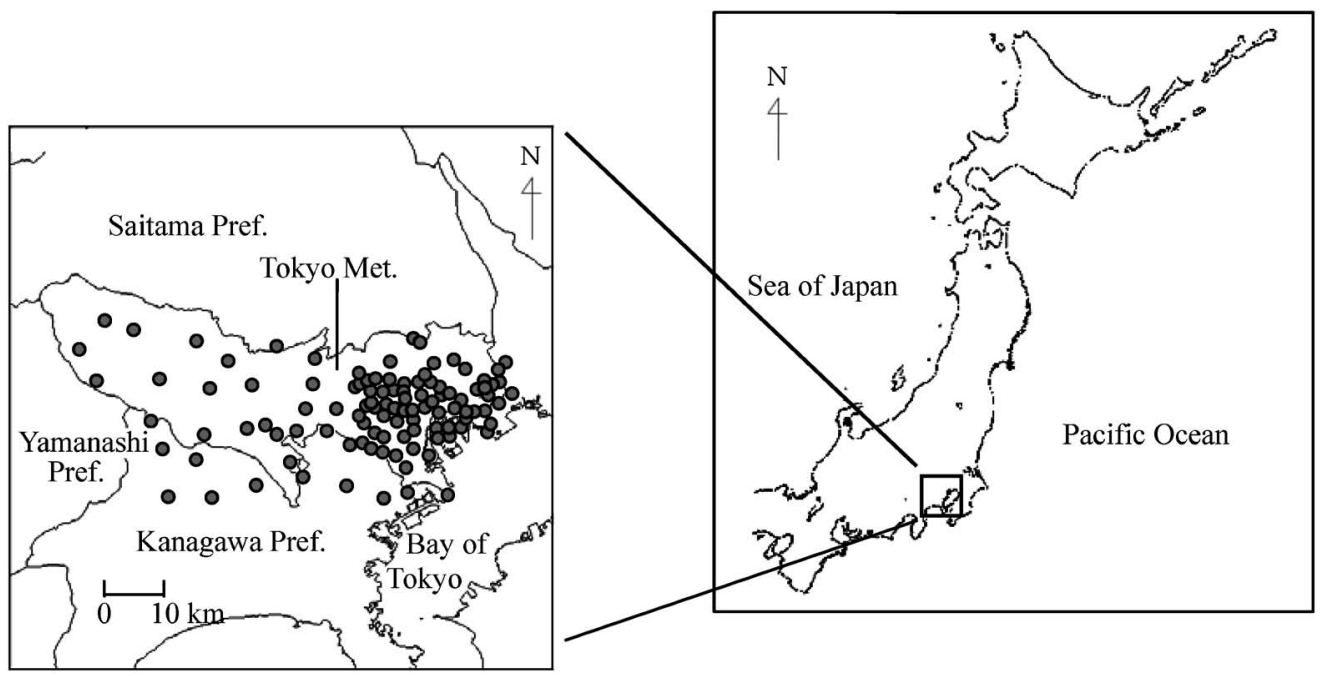

Fig. 1 Sampling sites of soil plotted in a map of Japan. 
料の重量 $(\mathrm{g})$

本研究で用いた試料中には, 強磁性物質（磁鉄鉱 など）が含まれることが多く，乾燥試料をそのまま の状態で測定に用いると本装置の測定範囲外になっ てしまうことから，二酸化ケイ素で希釈し測定を行 った．今回の実験では, 試料 $40 \mathrm{mg}$ に二酸化ケイ素 $360 \mathrm{mg}$ を加えて希釈し，アルミナ乳鉢で粉砕して 十分混合したものを測定試料とした。磁気天秤（シ エアウッド製 MSB-MK1）を使用し，磁気天秤用試 料測定管（標準サイズ $0.324 \mathrm{~mm} \phi$ ）に試料を充填さ せることにより測定を行った。

混合物の質量磁化率は，各成分の質量磁化率の和 で表すことができるため, 混合試料で求めた質量磁 化率の值から二酸化ケイ素の值を差し引くことで, 乾燥試料の質量磁化率を求めることができる．換算 式は以下のと抢りである.

$$
\chi_{g}=\frac{m_{s}}{m_{s}+m_{o}} \chi_{s}+\frac{m_{o}}{m_{s}+m_{o}} \chi_{o}
$$

$\chi_{g}$ : 混合試料の質量磁化率, $m_{s}$ : 乾燥試料の重 量 $(\mathrm{g}), m_{o}:$ 二酸化ケイ素の重量 $(\mathrm{g})$

$\chi_{s}$ : 乾燥試料の質量磁化率, $\chi_{o}$ : 二酸化ケイ素 の質量磁化

今回の実験では，元の土砂試料を10倍に希釈して 測定したので， $\chi_{s}=10 \chi_{g}+\chi_{o}$ として乾燥試料の質量 磁化率を求めた.

\section{3. 蛍光 $\mathbf{X}$ 線分析}

土砂試料は様々な物質の混合物であるため，バル クの元素組成が異同識別の指標となりうる。そこ で, 洗浄済みの試料について蛍光 X 線分析を行っ た。試料約 $100 \mathrm{mg}$ をアルミナ乳鉢で粉砕し，錠剂 を作成したものを測定試料とした．アルミナ乳鉢か らのコンタミネーションは土砂中の $\mathrm{Al}$ 量に比べ少 量であるため無視できる程度である。試料は（株） リガクから購入したポリプロピレン膜の中に封入 し，試料ホルダーにセットした，装置は，日本電子 （株）製のエネルギー分散型蛍光 $\mathrm{X}$ 線分析装置 （JSX-3200）を用いた。

本装置を用いた測定において，全ての試料から得 られた 7 元素, $\mathrm{Al}_{2} \mathrm{O}_{3}, \mathrm{SiO}_{2}, \mathrm{~K}_{2} \mathrm{O}, \mathrm{CaO}, \mathrm{MnO}, \mathrm{Fe}_{2}$ $\mathrm{O}_{3}, \mathrm{SrO}$ の重量パーセントをバルク $\mathrm{FP}$ 法にて計算 した. 求めた重量パーセントについて多変量解析で
ある主成分分析法を行い, 試料の特性化を試みた。 解析処理は, (株) 社会情報サービス製のエクセル 統計97を用いて行った.

\section{4. 粉末 X 線回折法}

蛍光 $\mathrm{X}$ 線分析では各試料における元素組成が求 められたが，さらに粉末 $\mathrm{X}$ 線回折法を相補的に用 いると結晶情報が得られ，含有鉱物を指標として用 いることができる。そこで，蛍光 X 線分析を行っ た試料のうち $\mathrm{Ca}$ を多く含む， $\mathrm{Fe}$ を多く含むなど 特徵的な組成を示す試料について粉末 X 線回折法 で測定を行った。洗浄済みの試料を再度, アルミナ 乳鉢で数 $\mu \mathrm{m}$ 程度に粉砕したものを測定試料とし て, (株) リガク製の粉末 X 線回折装置（RINT $2500: \mathrm{Cu}$ ターゲット/出力 $50 \mathrm{kV}, 100 \mathrm{~mA}$ ) で測定 を行った。

微細試料の個別測定は, 実体顕微鏡下で選り分け た後, ガンドルフィーカメラによる結晶性物質の同 定分析を行った． X 線源には $\mathrm{Cu}$ 管球を用い, 出力 $30 \mathrm{kV}, 15 \mathrm{~mA}$ で測定を行った.コリメーターで500 $\mu \mathrm{m}$ に絞った $\mathrm{X}$ 線を, 直径 $100 \mu \mathrm{m}$ 程度のガラス棒 の先端に接着剂を用いて固定させた試料に約 3 時間 照射し，回折データを富士写真フイルム（株）製の イメージングプレート（BAS-IP MS 2025）に露光 させた。（株）リガク製のイメージングプレートデ ィテクター（R-AXIS DS3C）を用いて回折データ を読み取り測定データとした。

\section{SEM-EDS}

微細試料の形態観察および組成分析のために SEM-EDS 測定を行った. 実体顕微鏡下で選り分け た微細試料を $\mathrm{Al}$ 試料板に固定し, カーボンを蒸着 させた。測定装置は，日立八イテクノロジーズ(株) 製のエネルギー分散型 X 線分析装置 (Kevex Sigma EDS）付き超高分解能走査型電子顕微鏡 $(\mathrm{S}-5000)$ を用いて加速電圧 $20 \mathrm{kV}$ にて形態観察および組成分 析を行った.

\section{6. 顕微鏡観察}

発見した球体について定量的に評価するため, 顕 微鏡観察を行った。観察は, 洗浄済及の試料, 重液 分離後の高密度フラクション, 低密度フラクション に関して，ニコン（株）製実体顕微鏡 SMZ-10（倍 率：×45〜60）を用いて行った. 各地点で採取した 
試料約 $150 \mathrm{mg}$ をスライドガラスにのせ，2-1 に示 した 6 種の人工球体に着目し 5 分間計数した.

\section{SR-XRF}

実体顕微鏡下で選り分けた人工球体について，重 元素組成の特徵をつかむために高エネルギー放射光 蛍光 X 線分析（SR-XRF）を行った。測定は，兵 庫県の高輝度光科学研究センターのSPring -8 （BL08W およびBL37XU）にて行った. BL08Wで は，ウィグラー光を $\mathrm{Si}(400)$ モノクロメーターで 単色化し, 励起エネルギーを $116 \mathrm{keV}$ とした.ビー ムサイズは $400 \mu \mathrm{m}$ (垂直方向) $\times 500 \mu \mathrm{m}$ （水平方向） であり，試料からの蛍光 X線を Ge-SSD で計測 し，積算時間は500秒とした. BL37XU では，アン シュレーターの高次光を $\mathrm{Si}$ (111) モノクロメーター で単色化し, 励起エネルギーを $75.5 \mathrm{keV}$ とした。 ビームサイズは $2 \mu \mathrm{m}$ (垂直方向) $\times 5 \mu \mathrm{m}$ （水平方 向）であり, Ge-SSD で計測し, 積算時間は100秒 とした。

\section{1. バルク試料の分析}

\section{結果および考察}

\section{1-1 高密度物質の存在率と質量磁化率}

重液分離により得られた各試料における高密度物
質の存在率を採取地点地図上（Fig. 2a）に示した. 地点ごとの特徵が明確になるように，白から黒に変 化するにつれて高密度物質の存在率が高くなるよう に 7 段階の濃淡で表した。最も高密度物質を多く含 んでいた地点では，採取した試料の $45 \%$ が高密度物 質であった. Fig. 2b の帯グラフは,「河川・池・湖」 や「公園」のような各区分に抢ける，高密度物質の 段階別の試料の割合を示したものである.

駅·道路から採取した試料は，高密度物質の存在 率の高い地点が多く, その 3 割の地点では $5 \%$ 以上 の高密度物質を含んでいたことが分かる。一方，河 川・池・湖から採取した試料に抢ける高密度物質の 存在率は, 比較的低い地点が多く, 半数の地点が 1 \%未満であることが分かった。

質量磁化率の測定結果を採取地点地図上（Fig. 3a）に示した. 最も質量磁化率の高い地点では, $2.3 \times 10^{-4} \mathrm{~m}^{3} \mathrm{~kg}^{-1}$ を示した. 地点ごとの特徵が明 確になるように，白から黒に変わるにつれて質量磁 化率が高くなるように 8 段階の濃淡で表した． Fig. $3 \mathrm{~b}$ の帯グラフは，「河川・池・湖」や「公園」のよ うな各区分における，質量磁化率の段階別の試料の 割合を示したものである.

「駅·道路」の試料は, 質量磁化率の高い地点が

\section{a}

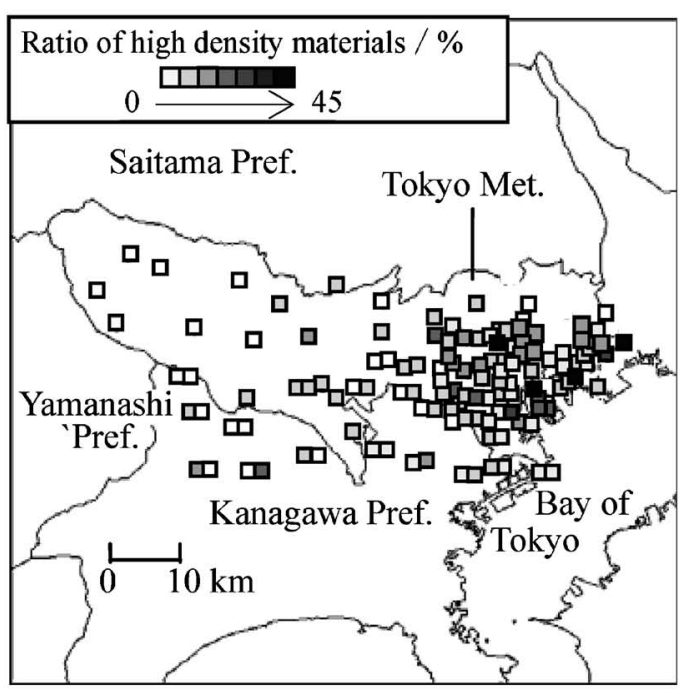

b

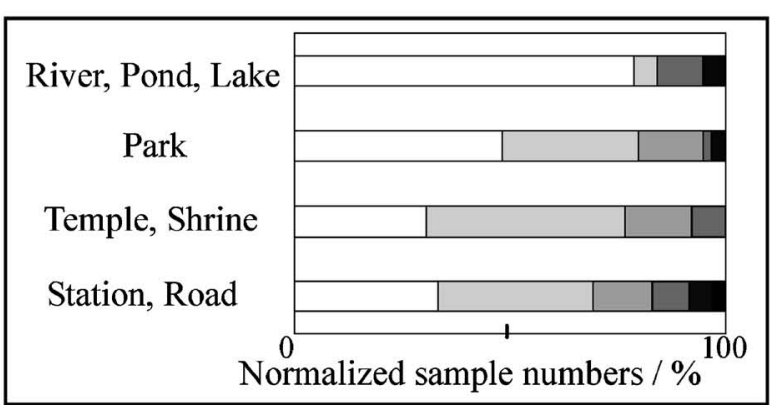

Fig. 2 Characterization of soil samples by their ratios of high density materials in the samples. (a) Geographical characteristic of the density of the samples expressed by the ratio of the high density materials. (b) A band graph showing the percentage of the each level of the high density material. 


\section{$\mathbf{a}$}

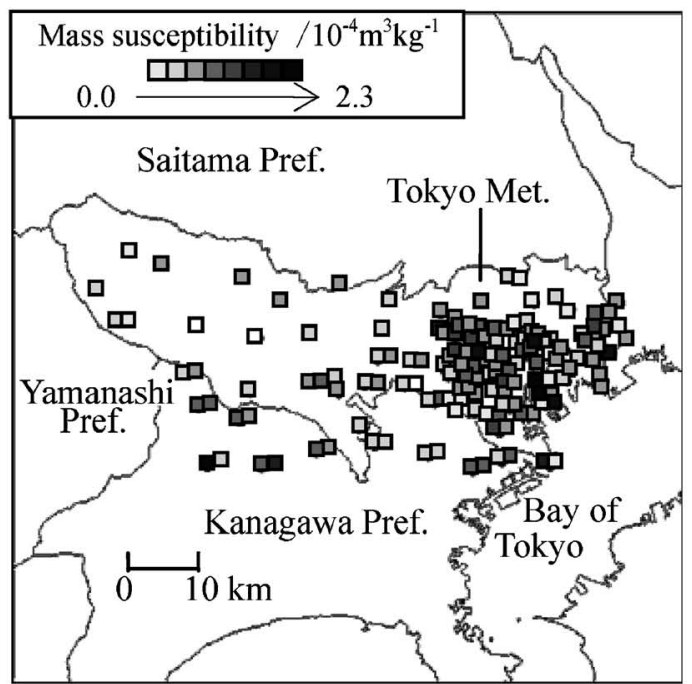

b

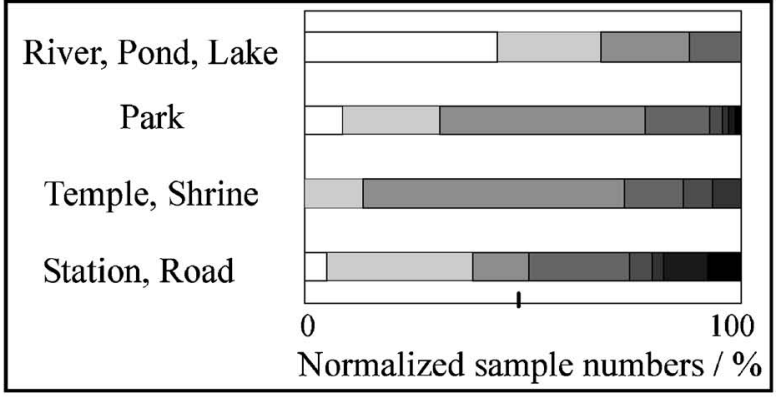

Fig. 3 Characterization of soil samples by their mass susceptibility. (a) Geographical characteristic of the susceptibility of the samples. (b) A band graph showing the percentage of the each level of the mass susceptibility of the samples.

多く，その $25 \%$ の地点が $0.5 \times 10^{-4} \mathrm{~m}^{3} \mathrm{~kg}^{-1}$ 以上で あることが分かる。一方，「河川・池・湖」の試料

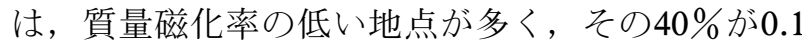
$\times 10^{-4} \mathrm{~m}^{3} \mathrm{~kg}^{-1}$ 未満であることが分かった。横軸に 高密度物質の存在率, 縦軸に質量磁化率をとり,

「駅前」や「公園」など地点の種類ごとにプロット した結果を Fig. 4 に示す。この図から明らかなよ うに，「河川・池・湖」の試料では, 高密度物質の 存在率, 質量磁化率がともに低い地点が多く, 逆に 「駅前・道路」の試料ではともに高い地点が多いこ とが分かった。また，高密度物質の存在率と質量磁 化率には正の相関が成り立っていて，相関係数は 0.62である. 地点の区分ごとの相関係数は, 河川 · 池・湖 $(0.31)$, 公園 $(0.08)$, 寺 - 神社 $(0.74)$, 駅. 道路（0.76）であった。相関係数の值から， 「寺・神社」,「駅·道路」の試料は「河川 - 池 · 湖」 の試料に比べて, 高密度物質の存在率と質量磁化率 の相関が強いことが明らかである。これらの試料に は, 密度, 磁化率の大きな鉱物, 微物の存在量が多 いことが示唆される. 一方，「公園」の試料では， 相関係数 0.08 となり，両者には相関がほとんど見い たされなかった。これは，公園を建設する段階で様 々な地域から土砂が運び込まれるために，顕著な一 般的傾向がなく，地点によって異なり，高密度物質

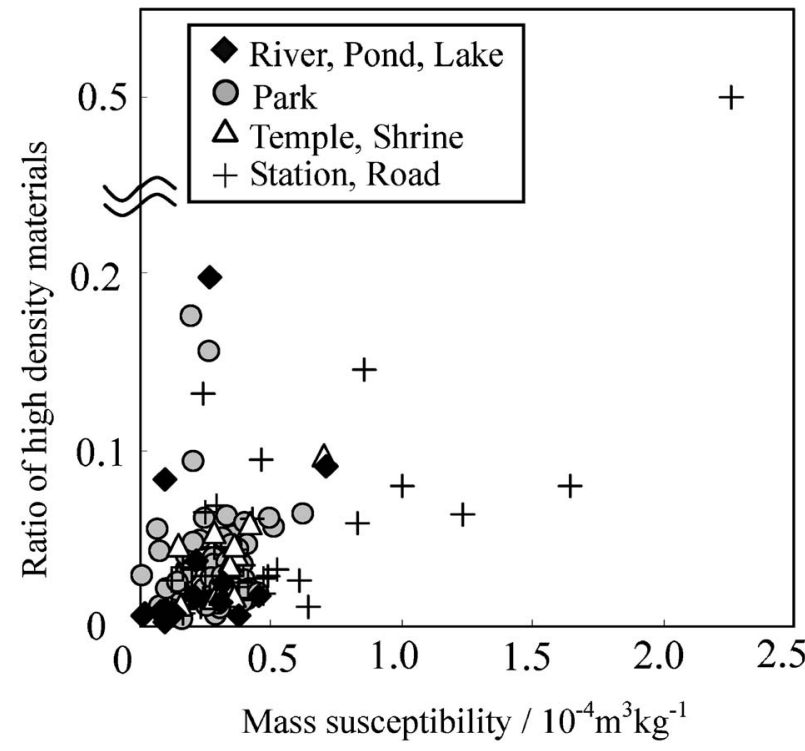

Fig. 4 Correlation diagram between percentage of the high density materials and that of the mass susceptibility.

と質量磁化率の両者は相関を示さなくなったと推察 できる.

\section{1-2 蛍光 $\mathbf{X}$ 線分析, 粉末 $\mathbf{X}$ 線回折分析}

蛍光 $X$ 線分析の結果から得られた 7 元素の重量 パーセントについて主成分分析を行い，得られた主 成分プロットを Fig. 5a，その因子負荷量を Fig. 5b 


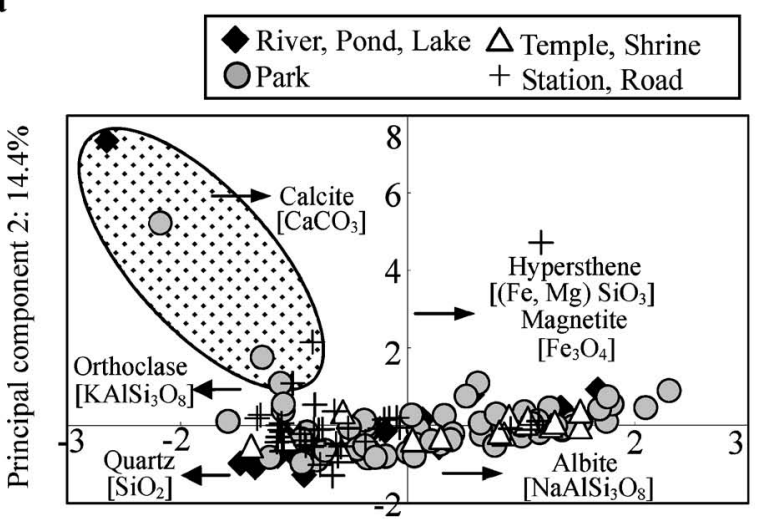

Principal component 1: $58.4 \%$ b

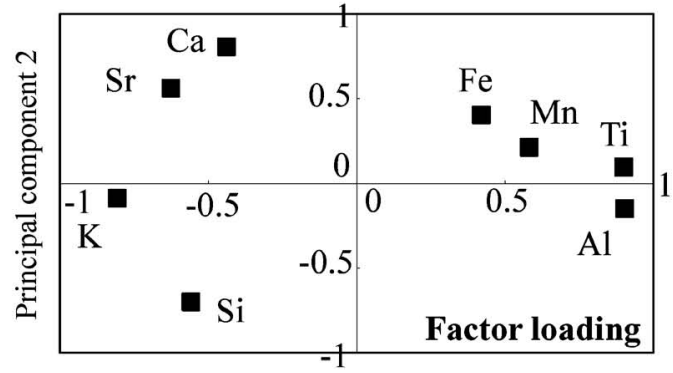

Principal component 1

Fig. 5 Principal component analysis of soil samples. (a) Score plot of the principal component 1 ( $\mathrm{x}$ axis) and the principal component 2 (y axis) and mineral names identified by XRD. (b) Factor loading plot of the principal component 1 ( $\mathrm{x}$ axis) and the principal component 2 (y axis).

に示す.

Fig. 5a から「駅・道路」の試料は鉄の含有量が 少ない傾向があった．質量磁化率の結果も考慮する と，鉄の含有量が少ないにもかかわらず，質量磁化 率の強い特徴のある地点と考えられる.これは鉄を 含む鉱物，微物の中でも磁化率の大きな值をもつ金 属鉄や酸化鉄のような強磁性体を含んでいることが 示唆される.一方，Fig. 5aにおいて，横軸に示す 主成分 1 の值が大きい「河川」,「公園」などの試料 は鉄の含有量が多くかつ質量磁化率が低い地点であ るといえる．これは鉄を含む鉱物，微物の中でもケ イ酸塩のような比較的質量磁化率の低い物質を多く 含むことが考えられる.

粉末 X 線回折分析の結果から，Ca 含有量が $10 \%$ を越える試料（Fig. 5a：網掛け部○）は方解石 $\left(\right.$ Calcite, $\left.\mathrm{CaCO}_{3}\right)$ の回折パターン (PDF: 5-586) ${ }^{17)}$ を示すことから, Ca 含有量は方解石の存在量に起 因して抢り，他の試料と識別可能であることが分か った。 また，主成分 1 (横軸) の值が大きい試料は 曹長石（Albite, $\mathrm{NaAlSi}_{3} \mathrm{O}_{8}$ ）の回折パターン （PDF: 9-466）が強く見られた。一方，主成分 1 の 值が小さい試料は石英 (Quartz, $\mathrm{SiO}_{2}$ ) と正長石 (Orthoclase, $\mathrm{KAlSi}_{3} \mathrm{O}_{8}$ ) の回折パターン (PDF: 33 -1161 (石英)；31-966（正長石））が見られた。一 般的に, 長石類は地殼中において $64 \%$ 程度を占める
鉱物であり 12$)$ ，本研究の試料においても測定結果に 大きく寄与していることが予想される. Fig. 5aで 試料が帯状になっているのもそのためで，K 含有量 の多い正長石を多量に含む試料は，主成分 1 の值が 負の位置に， $\mathrm{K}$ 含有量の少ない曹長石を多く含む試 料は主成分 1 の值が正の高い位置に分布していると 考察できる.さらに，特異的に鉄含有量の多い試料 に颃いては，鉄を含む鉱物であるシソ輝石 (Hypersthene) や磁鉄鉱（Magnetite）の存在が認 められた.

\section{2. 個別粒子の分析}

\section{2-1 発見された様々な球体}

各地採取試料の重液分離後の高密度フラクション について顕微鏡で観察した結果, 数種の球体が特徵 的に認められた。外見から識別できる(1)ガラス球 体，(2)黑色球体，(3)白色球体の3つについての分析 を行った. SEM-EDSによる測定結果を Fig. 6 に， 高エネルギーSR-XRFの結果をFig. 7, 地点別の 分布図を Fig. 8 に示す.

(1)ガラス球体

透明で光沢をもつガラス様の球体は，大きさ約 0.1〜 $1 \mathrm{~mm}$ であった (Figs. 6a, b). ガンドルフィー カメラ法による $\mathrm{X}$ 線回折ではアモルファスである ことから，この球体はガラスであることが確認でき た。これらのガラス様の球体について SEM-EDS 

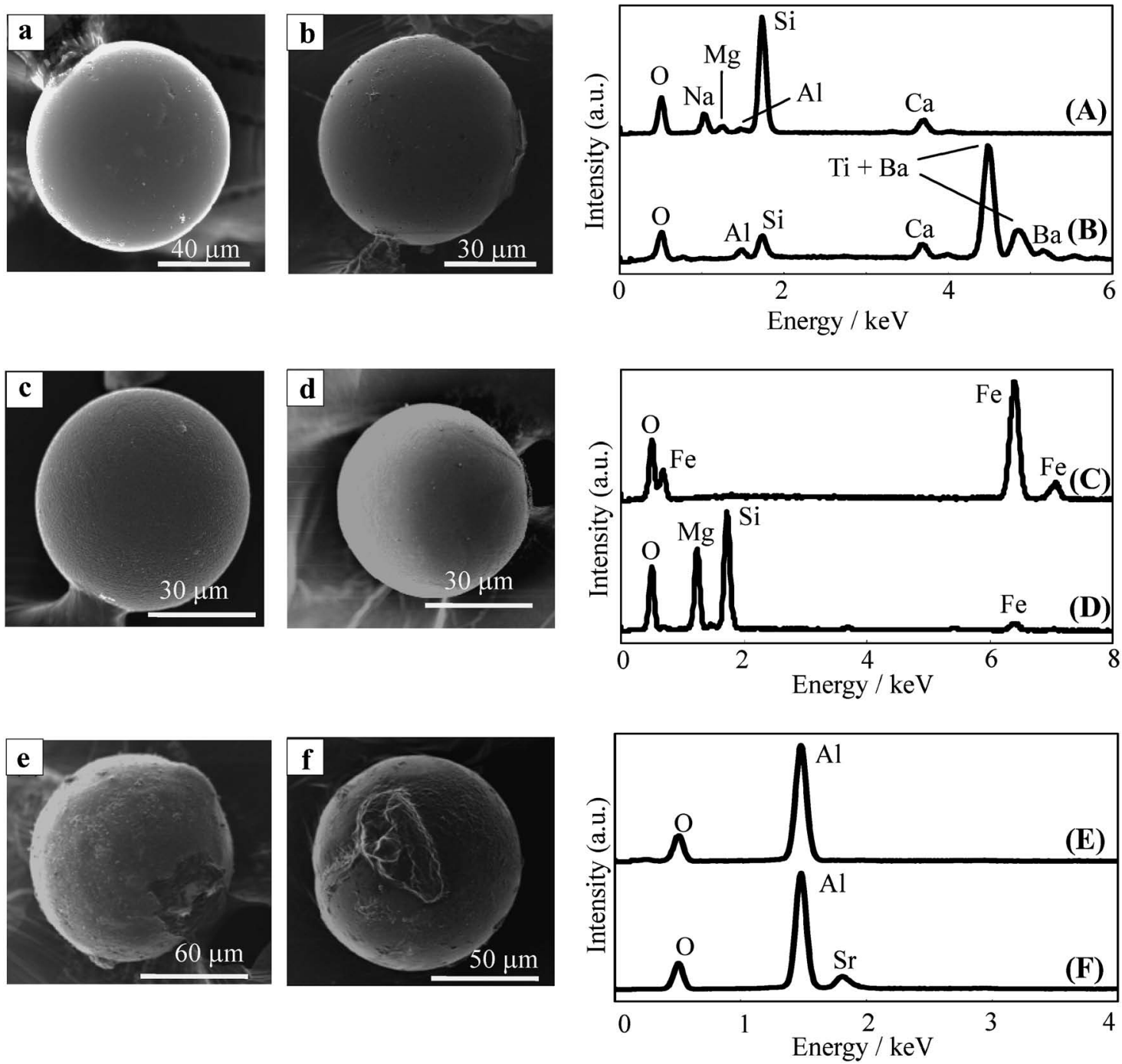

Fig. 6 SEM images (left) and the EDS spectra (right) of 6 types of the spherule samples. SEM image was obtained by using secondary electrons. (a) and (A): transparent spherule $(\mathrm{Na}-\mathrm{Ca}-\mathrm{Si}-\mathrm{O}$ type), (b) and (B): transparent spherule (Ba-Ti-Si-O type), (c) and (C): black spherule (Fe-O type), (d) and (D): black spherule $(\mathrm{Si}-\mathrm{Mg}-\mathrm{O}$ type), (e) and (E): white spherule (Al-O type), (f) and (F): white spherule ( $\mathrm{Sr}-\mathrm{Al}-\mathrm{O})$.

分析を行った結果， $\mathrm{Na}-\mathrm{Ca}-\mathrm{Si}-\mathrm{O}$ 系 (Fig. 6A) と $\mathrm{Ba}-\mathrm{Ti}-\mathrm{Si}-\mathrm{O}$ 系 (Fig. 6B) の 2 種類存在することが 分かった。このようなガラス球体は道路の白線など (ロードマーク) に含まれる反射材（ガラスビーズ） として使用されているものであると考えられる18). 日本に抢いてガラスビーズは数社により製造, 販売 されており，ロードマークに使用されているガラス ビーズは主に $\mathrm{Na}-\mathrm{Ca}-\mathrm{Si}-\mathrm{O}$ 系のガラスである.

$\mathrm{Na}-\mathrm{Ca}-\mathrm{Si}-\mathrm{O}$ 系のガラス球体を高エネルギー SRXRF で分析した結果の一例を Fig. 7a に示す. Sr,
$\mathrm{Zr}, \mathrm{Ba}$ の 3 元素が検出され, このガラス球体から はいずれも同様のスペクトルが得られた。一方, $\mathrm{Ba}-\mathrm{Ti}-\mathrm{Si}-\mathrm{O}$ 系のガラス球体を高エネルギーSRXRF で測定した結果の一例を Fig. 7b に示す. Ba の強いピークに由来するエスケープピークが見られ た.このガラス球体は, 高輝度ビーズと呼ばれ, 高 屈折率で光をよく反射する特性をもつ. 従って交通 危険個所などには有効であるが，比較的高価である こと, 比重が重いため路面標示材内に沈むなどの欠 点から使用量は少ない. 実際に本研究においても, 

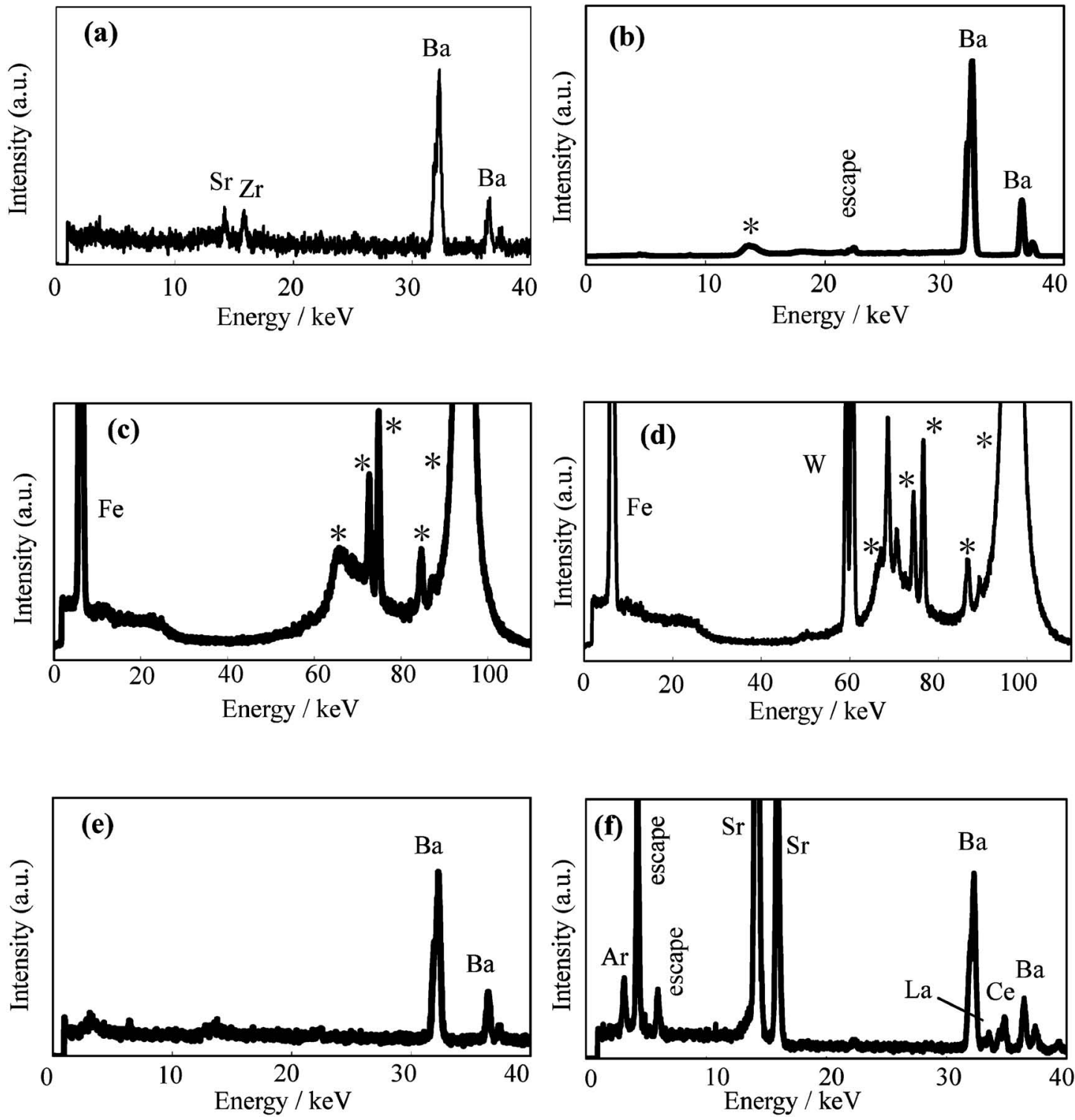

Fig. 7 X-ray fluorescence spectra obtained by high-energy SR-XRF analysis of the spherules. (a) Transparent spherule $(\mathrm{Na}-\mathrm{Ca}-\mathrm{Si}-\mathrm{O}$ type $)$, (b) transparent spherule $\left(\mathrm{Ba}-\mathrm{Ti}-\mathrm{Si}-\mathrm{O}\right.$ type), (c) and (d) black spherules $\left(\mathrm{Fe}^{-}\right.$ O type), (e) white spherule ( $\mathrm{Al}-\mathrm{O}$ type), (f) white spherule $(\mathrm{Sr}-\mathrm{Al}-\mathrm{O}$ type). * : peak derived from the instrument.

浅草橋で採取された試料などからしか発見されてい ない（Fig. 8A）。このことから，Ba-Ti-Si-O 系の ガラス球体は，存在量が少ないために試料の特性化 に有効な証拠試料となりうることが示唆され，重元 素組成においては著しい特徵が見られなかったこと から，SEM-EDS を用いれば簡便に $\mathrm{Na}-\mathrm{Ca}-\mathrm{Si}-\mathrm{O}$ 系 のガラス球体と $\mathrm{Ba}-\mathrm{Ti}-\mathrm{Si}-\mathrm{O}$ 系のガラス球体を識別 できることが分かった。
(2)黒色球体

黒色球体は，黒色で金属光沢をもつ球体であり大 きさは約 $0.1 \sim 1 \mathrm{~mm}$ である (Figs. $6 \mathrm{c}, 6 \mathrm{~d}$ )。これら の黒色球体を SEM-EDS で分析した結果， $\mathrm{Fe}-\mathrm{O}$ 系 (Fig. 6C) と $\mathrm{Si}-\mathrm{Mg}-\mathrm{O}$ 系（Fig. 6D）の 2 種類存在 することが分かった．表面を観察すると，滑らかな もの，ザラザラしているものなど様々であるが，組 成との関連性はなかった。

$\mathrm{Fe}-\mathrm{O}$ 系の黑色球体についてガンドルフィーカメ 
A
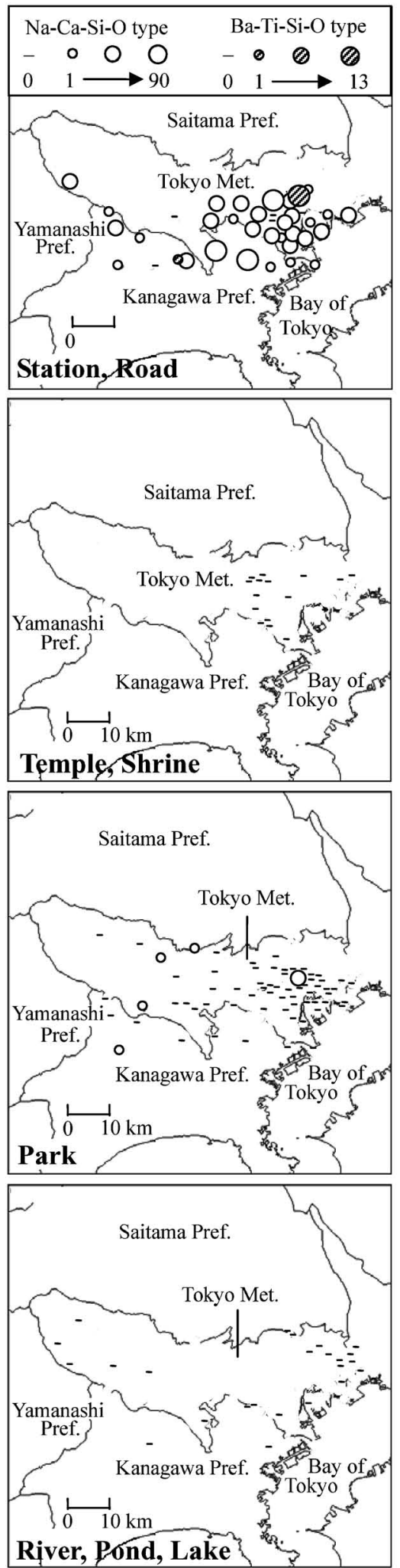

B
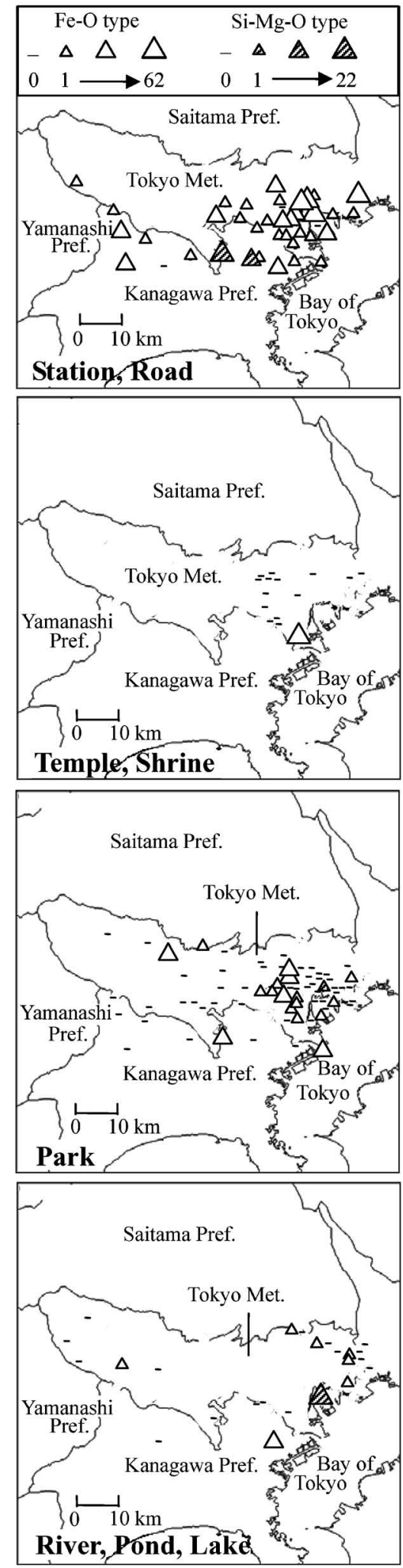

C
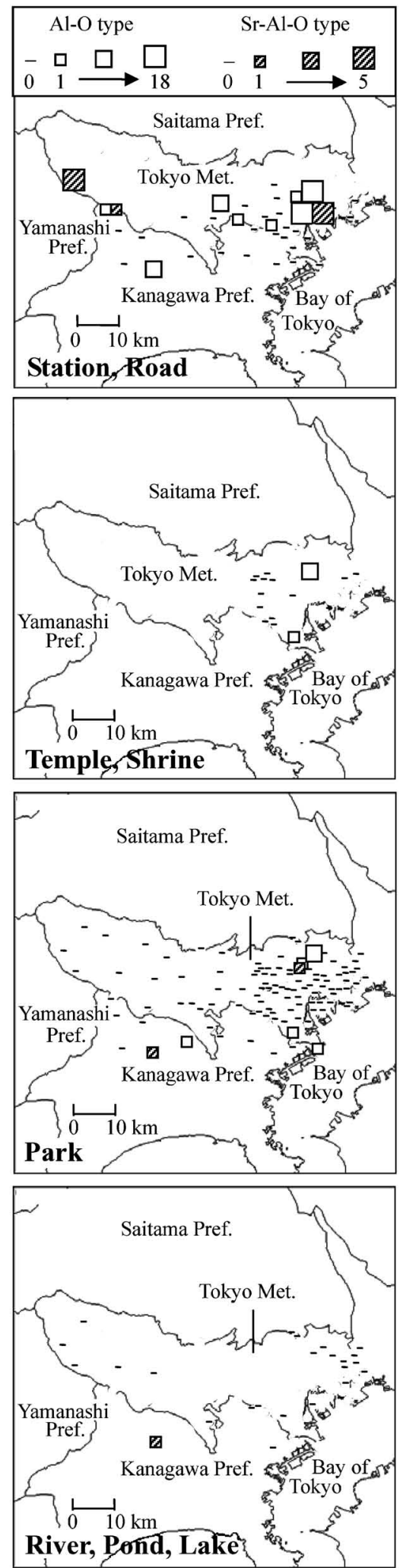

Fig. 8 Geographical characteristic of the spherule samples. (A) Transparent spherules, (B) black spherules, (C) white spherules. Each point was classified to 4 levels based on the number of spherule samples found in 150 mg of sample for 5 minutes counting under an optical microscope. 
ラを用いてX線回折分析を行った結果，赤鉄鉱 $\left[\mathrm{Fe}_{2} \mathrm{O}_{3}\right]$ の粉末回折パターンを示すことが分かっ た.この球体は金属の溶接の際にできる金属の球体 であり，溶接球と呼ばれるものと考えられる．溶接 する金属の種類や溶接条件によって成分や組成比が 異なることが報告されている19,20)．顕微鏡観察にお いて，溶接球は主成分が鉄であるため磁石を用いて 容易に分別することが可能であり，非常に多くの地 点で発見することができた。また，高エネルギー SR-XRF の結果の一例を Figs. 7c, 7d に示す. いず れも $\mathrm{Fe}-\mathrm{O}$ 系の黒色球体のものであるが，Wを含 有するものとしないものの 2 種類存在することが分 かった。

$\mathrm{Si}-\mathrm{Mg}-\mathrm{O}$ 系の黒色球体について X 線回折を行っ た結果, 頑火輝石 $\left[(\mathrm{Mg}, \mathrm{Fe}) \mathrm{SiO}_{3}\right]$ の回折パター ンを示す球体であることが分かった。この球体は鋳 物の製造に使用される低膨張鋳物砂であると考えら れる21)．お台場海浜公園で採取した試料など限られ た地域からしか発見されない稀な球体である（Fig. 8B）ことから，試料の特性化に有効な証拠試料々 なりうることが示唆された. 黒色球体についても,

$\mathrm{W}$ 以外の重元素組成に特徵が見られないことか ら, SEM-EDS を用いれば黒色の 2 種類の球体を簡 便に識別できることが分かった。

(3)白色球体

白色球体は, 白色で表面に光沢をもつ球体であ り，大きさは約 $0.1 \sim 1 \mathrm{~mm}$ である (Figs. 6e, f).こ れらの白色球体をSEM-EDS で測定した結果, $\mathrm{Al}-$ $\mathrm{O}$ 系 (Fig. 6E) と $\mathrm{Sr}-\mathrm{Al}-\mathrm{O}$ 系 (Fig. 6F) の 2 種類 存在することが分かった.

$\mathrm{Al}-\mathrm{O}$ 系の白色球体について X 線回折を行った結 果, アルミナ $\left[\mathrm{Al}_{2} \mathrm{O}_{3}\right]$ の回折パターンを示す球体 であることが分かった。用途としては研磨剂に使用 されていた可能性がある.この球体の高エネルギー SR-XRFの結果の一例を Fig. 7e に示す. Ba のみが 検出され, Fig. 7a に示した $\mathrm{Na}-\mathrm{Ca}-\mathrm{Si}-\mathrm{O}$ 系のガラ ス球体と似たようなスペクトルが得られた.

$\mathrm{Sr}-\mathrm{Al}-\mathrm{O}$ 系の白色球体について X 線回折を行っ た結果, アルミン酸ストロンチウム $\left[\mathrm{SrAl}_{12} \mathrm{O}_{19}\right]$ の回折パターン（PDF: 26-0976）を示すことが分 かった．用途としては蓄光材などに使用されている
可能性がある.この球体の高エネルギーSR-XRF の結果の一例を Fig. 7f に示す．ストロンチウムの 強いピークとこれに由来するエスケープピークが見 られ，他にも $\mathrm{La}, \mathrm{Ce}$ などの希土類元素, $\mathrm{Ba}$ も検出 された.これらの白色球体は他の球体に比べて存在 量が極端に少ないため，存在するだけで試料の特性 化に有効な証拠資料となりうることが示唆された.

ただし，X線回折やSEM-EDS では顕著な差が出 にくいため, 今回実施していない微小部蛍光 X 線 分析を用いればより簡便に識別可能であると思われ る. また, $\mathrm{Sr}-\mathrm{Al}-\mathrm{O}$ 系の白色球体では複数の重元 素が認められたことから, 重元素組成によってさら にこの球体を細分化できることから，より有用な証 拠資料となりうる可能性がある.

\section{2-2 球体の分布}

Fig. 8 は 6 種の人工球体について採取地の区分ご とに分布を示した図である.ガラス球体の分布図を Fig. 8A に, 黒色球体の分布図をFig. 8Bに, 白色 球体の分布図を Fig. 8C に示した。分布図は「駅. 道路」から採取した試料,「寺・神社」から採取し た試料，「公園」から採取した試料，「河川・池・湖」 から採取した試料に区分して表記した．各々の図 で, 発見された球体の数に応じて 3 段階にわけ, 球 体の数が多い地点ほど大きな表記記号で表し, 球体 が 1 も全く発見できなかった地点では「一」と表 記した. 図から，「駅・道路」の試料は「公園」な どの他の地点に比べて球体が多数存在していること が明らかであり，なかでも $\mathrm{Na}-\mathrm{Ca}-\mathrm{Si}-\mathrm{O}$ 系のガラ 又球体と $\mathrm{Fe}-\mathrm{O}$ 系の黒色球体は大量に発見された. 逆に, $\mathrm{Ba}-\mathrm{Ti}-\mathrm{Si}-\mathrm{O}$ 系のガラス球体と $\mathrm{Si}-\mathrm{Mg}-\mathrm{O}$ 系 の黑色球体, 白色球体は発見される地点に偏りがあ り，存在するだけでその地点の特徵を示す物質であ る.このように，今回発見した球体は場所により特 徵的な分布を示して抢り科学捜査のために有効であ ることが明らかとなった。

\section{結 論}

本研究では, 首都圏の土砂試料148点に関して様 々な測定法を駆使して，特性化を試みた。バルク試 料の分析では, 高密度物質の存在率, 質量磁化率を 比較することで, 駅や道路の試料に特徵があること 
が分かった. また, 粉末 $\mathrm{X}$ 線回折, 蛍光 $\mathrm{X}$ 線分析 のデータから主成分分析を行うことで， Fe や Ca を多く含む試料に特徵があることが分かった。一 方，顕微鏡観察により認められるガラス球体，黒色 球体, 白色球体は場所により特徵的な分布を示して おり，科学捜査のために有効な証拠試料となること が明らかとなった。現在, 高密度フラクションにお ける天然鉱物のうち重鉱物に着目して研究を進めて おり，ガンドルフィーカメラ法を用いた一粒の分析 方法の開発を行っている.

\section{謝 辞}

本研究に際し, 御指導, 御助言を頂いた科学警察 研究所の杉田律子氏，警視庁科学捜査研究所倉田正 治氏，ガラスビーズに関連する様々な情報を提供し て頂いた株式会社ユニオン・開発部の皆様に深謝致 します。また土砂試料の採取に際しては, 当研究室 の野瀬清仁, 米子敬洋, 両氏の協力をいただきまし た.な打, 本研究の一部は高輝度光科学研究セン ター, SPring-8 の研究課題 (Proposal No. 2002B0693 -NS2-np/BL08W）として遂行されました.

\section{文 献}

1）瀬田季茂, 井上堯子：犯罪と科学捜査, 東京 化学同人, 東京 (1998).

2) Junger, E. P.: Assessing the Unique Characteristics of Close-Proximity Soil Samples: Just How Useful Is Soil Evidence?, J. Forensic Sci., 41 (1), 27 (1996).

3) Cleveland G. B.: CDMG helps find kidnapper, California Geology, 26, 240 (1973).

4) Marumo, Y.: Forensic Examination of Soil Evidence, 鑑識科学, 7(2), 95 (2003).

5) Sugita, R. and Marumo, Y.: Validity of color examination for forensic soil identification, Forensic Sci. Int., 83, 201 (1996).

6) Sugita, R. and Marumo, Y.: Screening of soil evidence by a combination of simple techniques: validity of particle size distribution, Forensic Sci. Int., 122, 155 (2001).

7) Hiraoka, Y.: A possible approach to soil dis- crimination using x-ray fluorescence analysis, $J$. Forensic Sci., 39(6), 1381 (1994).

8) Graves, W. J.: A mineralogical soil classification technique for the forensic scientist, J. Forensic Sci., 24, 323 (1979).

9) Janssen, D. W., Rulf, W. A. and Prichard, W. W.: The use of clay for soil color comparisons, $J$. Forensic Sci., 28, 773 (1983).

10) Wanogho, S., Gettinby, G., Caddy, B. and Roberston, J.: Determination of particle size distribution of soils in forensic science using classical and modern instrumental methods, J. Forensic Sci., 34, 823 (1989).

11）中井泉：犯罪と分析化学, ぶんせき, 10, 591 (2002).

12）森本信男：造岩鉱物学, p. 13, 東京大学出版 会, 東京 (1971).

13）檀原 徹, 岩野英喜, 糟谷正雄, 山下 徹, 角井朝昭：無毒な重液 SPT（ポリタングステン 酸ナトリウム）とその利用, 地質ニュース,

455, 31 (1992).

14）中羊田義博：Gandolfi カメラを用いた微小結 晶の格子定数の測定, 鉱物学雑誌, $22(3), 113$ (1993).

15）中牟田義博：X線回折法による極微小鉱物の 精密分析, 鉱物学雑誌, $28(3), 117$ (1999).

16）井口洋夫, 大東典子, 相原惊一 : 磁気化学入 門, p. 105, 培風館, 東京 (1970).

17) "Powder Diffraction File, PDF", International Centre for Diffraction Data, U.S.A., (2003).

18）（株）ユニオン：製品案内（ロードマーキン グ用ユニビーズ), http://www.unibeads.com/

19）最上和生, 坂田八昭, 柏谷一弥: 被膜アーク 溶接棒種別の識別について, 科警研報告, 28 (4), 43 (1975).

20）最上和生, 斉藤修二, 牧下 寛: SEM および EDS によるスパッタの識別, 科警研報告法科学 編, 42(1), 29 (1989).

21）易宏治, 半田勝郎, 大橋 明: 球状低膨張 鋳物砂の開発, http: / / www.yks-net.co.jp / kouengaiyo/021006.pdf 